\title{
A STUDY ON THE USE OF FECAL CHARACTERISTICS FOR FEED DIGESTIBILITY DETERMINATION IN GOAT
}

\author{
S.A.B. Santoso, G. Puspitasari, A. Muktiani, Sunarso and A. Purnomoadi \\ Faculty of Animal and Agricultural Sciences, Diponegoro University \\ Tembalang Campus, Semarang 50275, Central Java - Indonesia \\ E-mail : agusbees@gmail.com
}

Received January 05, 2015; Accepted February 18, 2015

\begin{abstract}
ABSTRAK
Penelitian ini bertujuan untuk mengekplorasi karakteristik fisik dan hubungan antara karakteristik fisik feses dengan kecernaan pakan pada kambing perah Peranakan Etawah (PE). Enam belas ekor kambing PE laktasi 2 dan periode laktasi bulan 4-5 digunakan sebagai materi penelitian, dengan rancangan acak kelompok berdasarkan produksi susu sebagai ulangan. Ransum yang diberikan mengandung protein kasar 16\% dan total digestible nutrients (TDN) $65 \%$ dengan perlakuan $\mathrm{T}_{0}$ : pakan tanpa urea; $\mathrm{T}_{1}$ : pakan dengan kandungan urea $0,4 \%$ bahan kering; $\mathrm{T}_{2}$ : pakan dengan kandungan urea $0,8 \%$ bahan kering; $\mathrm{T}_{3}$ : pakan dengan kandungan urea 1,2\% bahan kering. Parameter yang diamati adalah kecernaan bahan kering pakan, kadar air feses, perluasan feses pipih (PFP) dan proporsi partikel kasar feses (PPKF). Data dianalisis dengan ragam dan uji korelasi-regresi untuk mengetahui hubungan antar parameter. Hasil penelitian menunjukkan bahwa level urea dalam pakan sebesar $0-1,2 \%$ bahan kering pakan tidak menyebabkan perbedaan kecernaan bahan kering, kadar air, tingkat PFP dan PPKF. Terdapat hubungan negatif kuat antara tingkat kecernaan bahan kering dengan kadar air feses $(\mathrm{r}=$ $-0,665)$ dan tingkat PFP $(r=-0,553)$, serta terdapat hubungan positif kuat antara tingkat kecernaan bahan kering pakan dengan tingkat PPKF $(r=0,608)$. Simpulan penelitian ini adalah kadar air feses, tingkat PFP dan PPKF dapat digunakan untuk mengetahui kualitas pakan yang diberikan. Apabila feses memiliki tekstur lebih halus, kering dan partikel kecil maka kecernaan pakannya lebih tinggi, sebaliknya apabila feses bertekstur kasar, basah, partikel besar maka kecernaan pakan lebih rendah.
\end{abstract}

Kata kunci : karakteristik, feses, kecernaan, kambing PE.

\section{ABSTRACT}

This study aimed to explore physical characteristics and its correlation to feed digestibility in goat. Sixteen Ettawah Grade goats in the second milk production periods and in the $4-5^{\text {th }}$ month of lactation were used in this study. The study was arranged with completely randomized block block design based on milk production as replications. The goats were fed ration containing $16 \%$ of crude protein and $65 \%$ of total digestible nutrients (TDN). Some of crude protein content were supplied by urea. The treatments were control ration (without urea; $\mathrm{T} 0$ ), ration with $0.4 \%$ urea (T1), ration with $0.8 \%$ urea (T2), and ration with $1.2 \%$ urea (T3). Parameters observed were feed digestibility, fecal extended level (FEL), and fecal rough particle distribution (FRPD). Data were analyzed using correlation-regression to find the correlation between fecal characteristics and feed digestibility. The results showed that urea content in the rations up to $1.2 \%$ of dry matter did not affect dry mater digestibility, water content and fecal characteristics (FEL and FRPD). There were highly negative correlation $(r=-0.665)$ between feed digestibility and water content of feces as well as feed digestibility and FEL ( $\mathrm{r}=-0.553)$, while correlation between digestibility and FRDP was positive $(r=0.608)$. The conclusion of this study was water content, degree of FEL and FRPD can be used to determine the quality of feed. If feces composed of finer texture, dried and small particles indicated having better digestibility, while if feces composed of rough texture, wet, and large particles indicated having low digestibility.

Keywords: characteristics, feces, digestibility, goat 


\section{INTRODUCTION}

Goat plays an important role in rural economic due to the easiness of raising, handling and low capital needed. These are some advantages of raising goats, especially dairy goat such as: Ettawah Grade goat in term of the price of goat milk which are relatively more expensive than those of cattle milk. However, up to now the milk production is still low, fluctuated and varied. This condition might be caused by poor anticipation on the change of milk production due to the month of lactation and different feedstuff given during rearing periods which may have different feed utilization. The feed utilization can be determined by its digestibility using digestion trials or indicator methods (Drennan et al., 1970; Weller et al., 1971). These methods are accurate and need several days to determine the feed digestibility, and therefore these methods were not practical.

One of promising methods to determine feed digestibility is by using fecal characteristics. The previous studies on the use of feces have been reported. The science that studies feces, called Scatology, has been done since 1920's (Seton, 1925) by exploring several types of information obtained from feces and their contents, such as for identifying the animal (Camardella et al., 2000), diet composition (Santos and Hartz 1999, Kauhala and Auniola 2001), seasonal diet changes (Aragona and Setz 2001), health condition, and potential enteroparasitosis dynamics (Patton et al. 1986, Page et al., 2001). Moreover, recently, feces could be used to determine starch digestion (Fredin et al., 2014; Zinn et al., 2007) as well as organic matter digestion (Lukas et al., 2005).

Theoretically, the more digestible feeds will be more degradable into smaller particles because it will give a better absorption due to wider surface to be penetrated by microbes or digestion enzymes. Remond et al. (2004) found that starch digestibility decreased with the increasing of particle size in their study using corn. This is similar to Lykos and Varga (1995) in their in situ study that reported a linear inverse relationship between the particle size and ruminal digestibility of corn (Lykos and Varga, 1995). Since the particle size of feed is influenced by chewing and rumination activities. This condition could affect the shape, characteristics, and the amount of feces particles that contribute to the characteristics of fecal consistency such as soft, hard, liquid, crushed and so on (Johnson and Taylor, 2001).
Based on the above explanation, it can be hypothesized that feces from highly digestible feeds will compose of smaller particle size and bigger extended level of feces than those from lowly digestible feeds. Therefore, this study aimed to explore the correlation between physical fecal characteristics and feed digestibility in order to provide a practical method to monitor feed utilization in animal farming system.

\section{MATERIALS AND METHODS}

\section{Animals and experimental design}

Sixteen lactation of Ettawah Grade goats with initial body weight of $47.2 \pm 1.9 \mathrm{~kg}(\mathrm{CV}=$ $11.9 \%$ ) at the second lactation periods were used in this study. These goats were in the $4-5^{\text {th }}$ month of lactation and having milk production range of $100-400 \mathrm{~g} /$ day. The goats were raised in an individual metabolic cage equipped with feeder and drinker separately.

The study was arranged with completely randomized block block design based on milk production as replications. The goats were fed ration containing $16 \%$ of crude protein and $65 \%$ of total digestible nutrients (TDN), Some of crude protein content were supplied by urea. The treatments were control ration (without urea; T0), ration with $0.4 \%$ urea (T1), ration with $0.8 \%$ urea (T2), and ration with $1.2 \%$ urea (T3). Goats were fed a single feed (mixed ration) in mash form with nutrients composition listed in Table 1. Parameters observed were feed digestibility, fecal extended level (FEL), and fecal rough particle distribution (FRPD).

\section{Experimental procedures}

The study was conducted in four stages, namely preparation, adaptation, treatment and data collection periods. At preparation stage, the goats were injected with vitamin (Injectamin $®$ ) at a dose of $2 \mathrm{~mL}$ per $25 \mathrm{~kg}$ of body weight to recover from stress during transportation, and

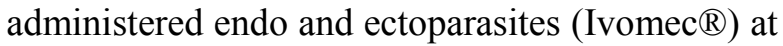
a dose of $1 \mathrm{~mL}$ per $25 \mathrm{~kg}$ of body weight to avoid the parasites effect on animal performance.

At the initial adaptation phase, the goats were weighed to determine the nutritional needs based on their body weight. Then, the goats were grouped based on the milk production and randomized to the treatments. Adaptation on feed to determine the goat's feed intake capacity for feeding treatment was lasted for 2 weeks. The feed requirement was calculated based on the 
Table 1. Feed Ingredients and Nutrients Composition of Feed in This Experiment

\begin{tabular}{lrrrr}
\hline \multicolumn{1}{c}{ Feedstuffs } & \multicolumn{1}{c}{ T0 } & T1 & T2 & T3 \\
\hline Wheat Stalk & 52.0 & 52.0 & 52.0 & 52.0 \\
Milled Corn and Cob & 17.0 & 17.2 & 17.4 & 18.0 \\
Cassava Waste & 0.3 & 0.5 & 1.2 & 1.5 \\
Coconut Meal & 8.8 & 8.9 & 8.4 & 8.2 \\
Wheat Bran & 7.0 & 7.8 & 8.3 & 8.9 \\
Soybean Meal & 12.0 & 9.6 & 7.6 & 5.2 \\
Molases & 2.5 & 3.2 & 3.9 & 4.6 \\
Urea & 0.0 & 0.4 & 0.8 & 1.2 \\
Mineral Premix & 0.4 & 0.4 & 0.4 & 0.4 \\
$\quad$ Total & 100.0 & 100.0 & 100.0 & 100.0 \\
Nutrient Contents & & & & \\
Crude Protein & 15.91 & 16.16 & 16.10 & 16.19 \\
Crude Fiber & 17.15 & 17.23 & 17.18 & 17.25 \\
Ether Extract & 2.12 & 2.06 & 2.02 & 1.96 \\
Nitrogen Free Extract & 58.52 & 58.45 & 58.69 & 58.64 \\
Ash & 6.30 & 6.10 & 6.01 & 5.96 \\
\hline
\end{tabular}

nutrients requirements and milk production according to NRC (1981). The treatment periods included data collection were done for 4 weeks.

\section{Digestibility and Fecal Characteristics Measurement}

In the last one week, the feed digestibility was measured using 7-days total collection methods. During this period, the feed given, the feed residual and the amount of feces excreted were weighed and sampled daily to determine the dry matter intake and feed digestibility. The calculation was done in dry matter base after all of the materials were oven-dried at $135{ }^{\circ} \mathrm{C}$ for 2 hours.

Fecal samples were used to determine the fecal characteristics such as water content, FEL and FRPD. Fecal characteristics were measured using fresh feces (less than 1 hour excreted). The water content of feces was determined by ovendried feces in $135{ }^{\circ} \mathrm{C}$ for 2.5 hours. The loss weight between before and after drying process was considered as water, and was calculated in the percentage.

Fecal extended level was measured on $10 \times 1$ pieces of goat feces of each treatment which was placed in the modified FEL equipment. The structure and the working procedure of this equipment are illustrated in Figure 1. The works of this tool are: 1) the $500 \mathrm{~g}$ or metal load was pull up to $7 \mathrm{~cm}$ height from the bottom (the $500 \mathrm{~g}$ load's weight and $7 \mathrm{~cm}$ height were determined by trial and error prior to fit for application), while 2) the feces was put on the point vertically of the load, and 3) when the load is released and fallen down, the feces will be flattened, and the surface area of feces will be wider. The wide area of feces was measured with millimeter block. The FEL was determined by subtracting the wide area after flattened with the wide area of feces intact. The value of FEL was calculated in the percentage.

The particle distribution of feces was determined by soaking the $25 \mathrm{~g}$ of feces in 1000 $\mathrm{ml}$ of water for 24 hours prior to be sieved gently to pass $1.0 \mathrm{~mm}$. The feces that cannot pass the 1.0 $\mathrm{mm}$ sieve were dried in $135{ }^{\circ} \mathrm{C}$ for 2 hours, weighed, and was percentaged to the initial fresh 
weight. The value of FRPD was percentaged.

\section{Data Analysis}

Correlation between the fecal characteristics and digestibility were analyzed by linear regression. Criteria of correlation strength was determined based on the $r$ value, such as no correlation $(\mathrm{r}=0.00)$, having weak correlation $(\mathrm{r}=>0.00-0.25)$, medium correlation $(\mathrm{r}=>0.25$ $0.50)$, strong correlation $(\mathrm{r}=>0.50-0.75)$, very strong correlation $(\mathrm{r}=>0.75-0.99)$, and complete correlation $(\mathrm{r}=1.00)$ (Sudjana, 2005).

\section{RESULTS AND DISCUSSION}

\section{The Effect of Urea Levels on Feed Intake}

The intakes of dry matter (DMI) and crude protein $(\mathrm{CP})$ of four feeding treatments are presented in Table 2. The DMI per body weight ranged from 2.71 to $3.12 \%$ was classified as normal in goat, being 2.0 to $5.0 \%$ of NRC (1981) or 2.0 to $4.7 \%$ of Devendra and Burn (1994). Some studies in Angora goats found that the DMI was varied from about $2.33-2.84 \% \mathrm{BW}$ under intensive rearing system (Trana and Sepe, 2008) to $3.3 \%$ of $\mathrm{BW}$ in extensive rearing (Bonanno et al., 2008).The DMI per kilogram of metabolic bodyweight (MBW; $\mathrm{BW}^{0.75}$ ) ranged at 67.38$78.72 \mathrm{~g} / \mathrm{kg}$ MBW was in normal range of Jamnapari goats which were reported at 40.5$127.3 \mathrm{~g} / \mathrm{kg}$ MBW (Devendra and Burn, 1983) and 34-104 g/kgMBW (Decandia et al., 2008). Variations of DMI per kilogram body weight were influenced by breeds, feedstuffs composed the feed and feed composition, body weight, maintenance requirements, ambient temperature and seasons (Devendra and Burn, 1994; Decandia et al., 2008).

The dry matter and crude protein intakes in this study were not significant. This result indicated that the urea contained in the ration up to $1.2 \%$ of DMI did not affect the palatability. The absence of differences among the treatments in DMI may also possibly due to the ration consisted of the same materials (Table 1) which was confirmed with the statement of Abdulah and Mirajuddin (2005). This study is also agreed to the study of Chanjula and Ngampongsai (2008)
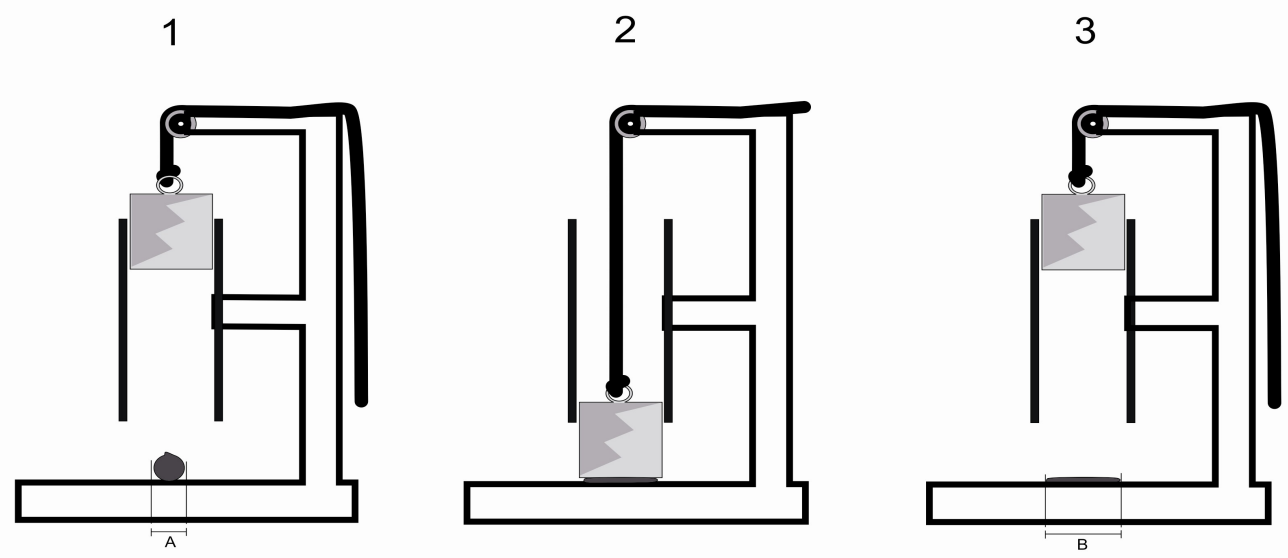

Figure 1. Structure and Working Procedures of FEL Equipment

Table 2. Dry Matter Intake of Four Feeding Treatments in this Study

\begin{tabular}{lrrrr}
\hline \multicolumn{1}{c}{ Parameters } & \multicolumn{1}{c}{ T0 } & \multicolumn{1}{c}{ T1 } & \multicolumn{1}{c}{ T2 } & \multicolumn{1}{c}{ T3 } \\
\hline Dry matter intake, g/day & 1343 & 1317 & 1270 & 1372 \\
Dry matter intake, g/kg MBW & 71.88 & 74.31 & 78.72 & 67.38 \\
Dry matter intake, \% BW & 2.71 & 2.85 & 3.12 & 2.47 \\
Crude protein intake, g/kgMBW & 11.30 & 11.84 & 12.67 & 10.68
\end{tabular}


that in the native Thailand crossed goats with Anglo Nubian fed ration containing urea up to 3\% DMI did not affect feed consumption and the digestibility.

\section{The Effect of Urea Levels on Feces Characteristics}

The results of the DM digestibility of feed, fecal water content, FEL and FRPD of goat are presented in Table 3. The feeding treatments did not give a significant differences on these parameters. This might be caused by the urea concentration in the feed at $0-1.2 \%$ did not affect microbial activity in the rumen fermentation process, therefore it did not cause differences in digestibility, so the substitution of urea to feed protein did not affect feed utilization. Another possible reason for explaining this phenomenon was that the Nitrogen and energy content in the rations were relatively the same in all of the treatments. When the availability of energy in feed was sufficient for rumen microbial activity, the sources of nitrogen feeds (including those derived from urea) did not affect microbial $\mathrm{N}$ synthesis as well as in nitrogen balance of goats (Asih et al., 2011). The DM digestibility in this study which ranged at $60.88-62.13 \%$ was higher than $55-56 \%$ that was reported by Preston and Leng (1987).

\section{The Correlation between Digestibility and Fecal Water Content}

The same digestibility value found in this study lead to the similar quality of fecal excreted by goat and give a similar value in FEL and FRPD. One of the factors affecting the FEL was the water content in feces. The data of this study showed that fecal water content was similar, ranging from 61.73 to $64.43 \%$.

The FRPD level of feeding treatment is presented in Table 3. Urea levels in feed did not affect the level of FRPD which was ranged at $21.44-22.44 \%$. This was related to the feed degradation in the digestive tract indicating that the opportunity of feed to be utilized in the digestive tract.

The correlation between feed digestibility and fecal water content in Ettawah Grade goats are presented in Figure 2. There was a negative correlation $(\mathrm{r}=-0.665)$ between DM digestibility $(\%)$ and fecal water content (\%). The results showed that DM digestibility of feed affected fecal water content, or by another words, the fecal water content indicated the digestibility of feed. From this correlation, the determinant of feed digestibility to fecal water content was $44.3 \%$. This presumably because feces excreted was derived from the same quality diets (Table 1 ), as proved by the similar DM digestibility (Table 2).

Water content of feces was a major factor that affected the texture of feces. The higher fecal water content made the softer fecal texture. This softer fecal texture would be resulted in faster passage in the digestive tract, and the digestibility will be lower. Fecal water content was influenced by the crude fiber levels of feed. The low crude fiber content in the diet resulted a high dry matter content in feces. In this study, the dry matter digestibility were ranging at $60.88-62.13 \%$, that were higher than $55-56 \%$ observed by Preston and Leng (1987). Meanwhile, the feeds with high crude fiber have a low digestibility (Tillman et al., 1998), and increase the water content of feces (Hafez and Dyer, 1969).

\section{Correlation between Feed Digestibility and Fecal Extended Level}

The correlation between DM digestibility (\%) and fecal extended level (FEL) (\%) is presented in Figure 3. There was a correlation $(\mathrm{r}=$ -0.553 ) between DM digestibility and FEL, with determinant factor of $30.5 \%$. The texture of feces

Table 3. Feed Digestibility and Fecal Characteristics

\begin{tabular}{lrrrr}
\hline Parameters & \multicolumn{1}{c}{ T0 } & \multicolumn{1}{c}{ T1 } & \multicolumn{1}{c}{ T2 } & \multicolumn{1}{c}{ T3 } \\
\hline DM digestibility (\%) & 62.13 & 62.03 & 61.88 & 60.88 \\
Fecal Water content (\%) & 64.43 & 63.55 & 62.33 & 61.73 \\
Fecal Extended Level (\%) & 140.33 & 144.50 & 146.90 & 144.43 \\
Fecal Rough Particle Distribution (\%) & 22.43 & 22.44 & 22.20 & 21.44 \\
\hline
\end{tabular}

*) All parameters among the treatments were not significant 


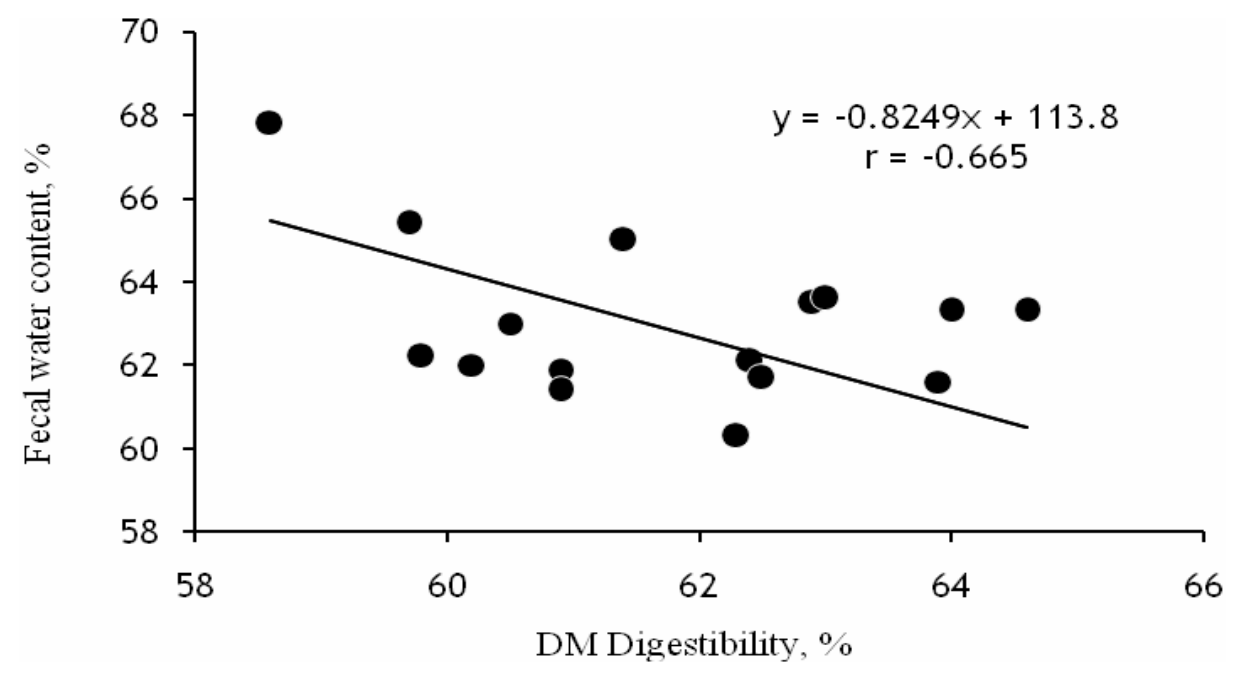

Figure 2. Correlation between DM Digestibility (\%) and Water Content (\%) in Feces

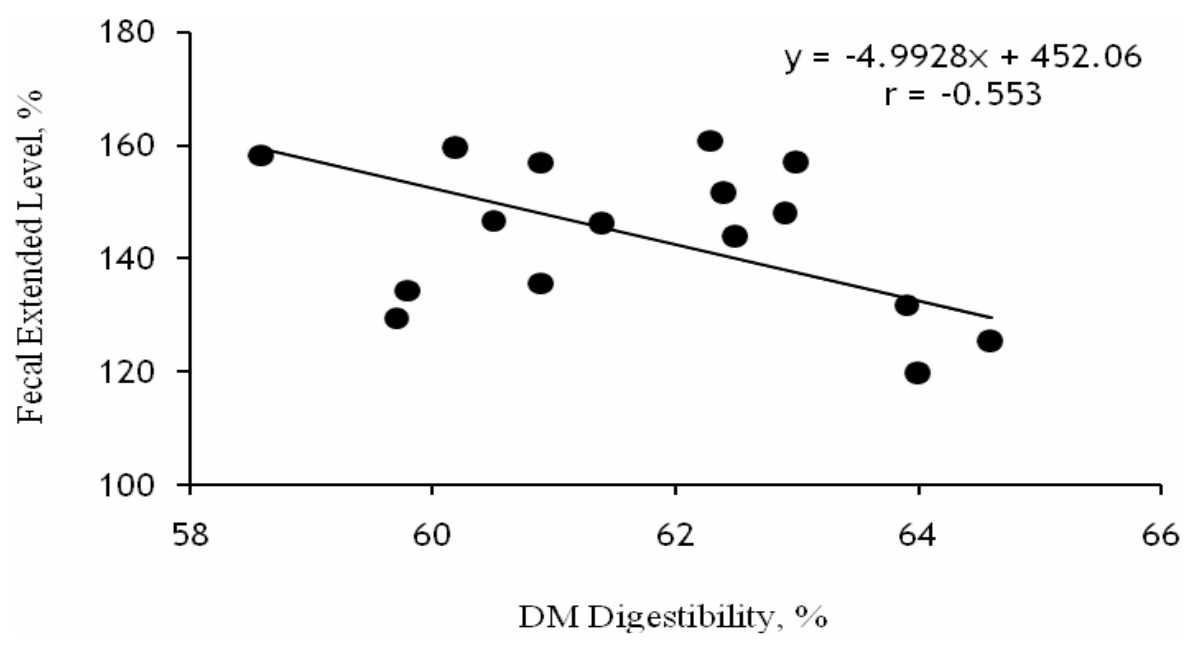

Figure 3. Correlation between DM digestibility (\%) and Fecal Extended Level (\%)

affected FEL. The harder texture produced smaller FEL; otherwise the softer texture produced broader FEL. These results were consistent with the relationship between dry matter digestibility and FEL. Lower digestibility of feed produced lower fecal water content and smaller FEL.

\section{Correlation between Feed Digestibility and Fecal Rough Particle Distribution}

The correlation between DM digestibility $(\mathrm{x})$ and fecal rough particle distribution (FRPD) (y) is presented in Figure 4. The correlation of DM digestibility and FRPD observed was positive $(r=$
0.608). The results showed that DM digestibility affected FRPD level, with determinant factor of $37.0 \%$. This phenomenon could be explained by the process of feed digested in the digestive tracts. Feed was broken down into smaller particle during mastication process in the mouth, then the feed particles move towards esophagus and reticulo-rumen. In the rumen, the feed received a degradation and fermentation process by microbial activity, and in addition, by friction between the feed particles due to rumen motility. The feed particle size met the size of reticuloomasal orifice (the tunnel connected rumen and omasum) will advance go to the omasum, 


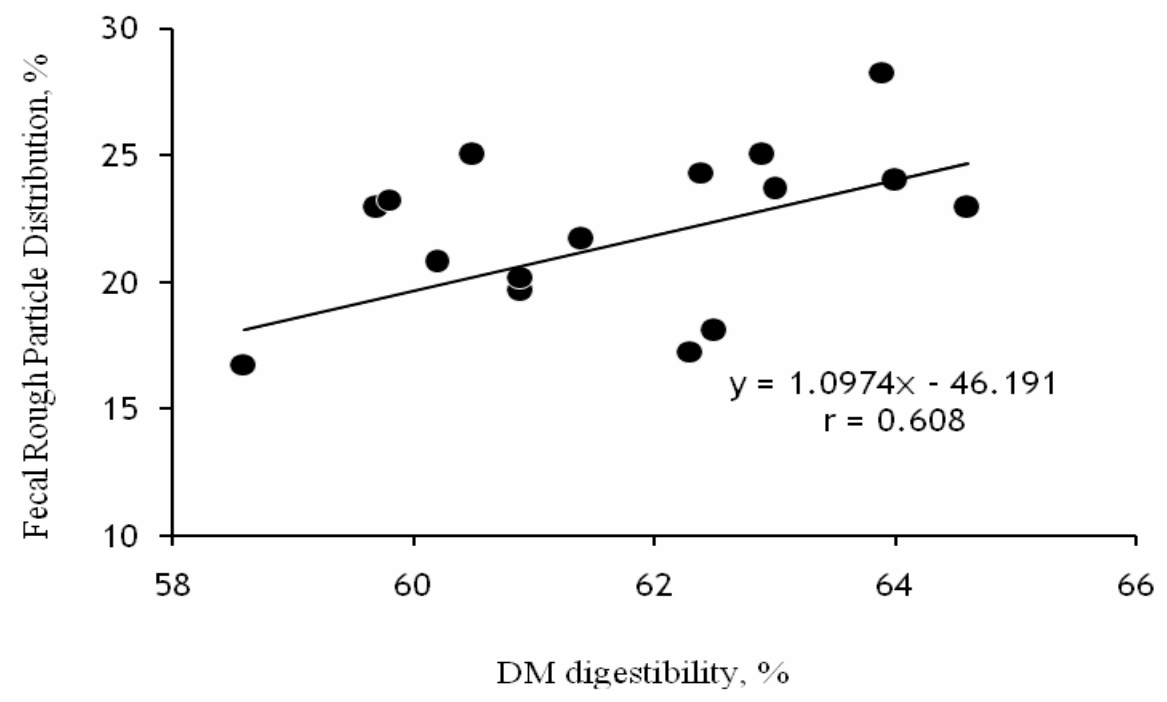

Figure 4. Correlation Between DM Digestibility (\%) and Fecal Rough Particle Distribution (\%)

abomasum and intestine (Ulyatt et al., 1986; Poppi et al., 1980), while particle size that still greater than the size of that orifice will be returned to the mouth for remastication to be degraded into smaller size and then was reswallowed. Meanwhile, the FEL was influenced by nutrients and water absorption by small and large intestine, respectively, from material passing through it prior to be excreted as feces (Stevens et al., 1979; Cunningham and Klein, 2007). By assuming that absorption rate was depend on the available nutrients could be absorbed, the nutrients contained in higher digestibility rations will be absorbed more than of the lower digestibility, and in turn proportionally remains higher water content in the feces. Therefore, the feed with a high digestibility will give higher FRPD.

\section{CONCLUSIONS}

Fecal water content, fecal extended level and fecal rough particle distribution in Ettawah Grade Goats have a correlation to feed digestibility, therefore, these characteristics could be used to determine feed quality, especially in farm usage. Feces had a finer texture, drier and smaller particles size indicated having better digestibility, otherwise if feces had rough texture, wet, and large particles size indicated having low digestibility. There was a strong negative correlation between DM digestibility with feces water content, and level of FEL, but positive with FRPD goat feces. This study also concluded that level of urea in the ration did not affect the correlation between fecal characteristics and feed digestibility.

\section{ACKNOWLEDGMENT}

The authors thanks to Triyatmo A. Nugroho and Ilham Habib for assistance during the experiment, especially in preparation of the equipment.

\section{REFERENCES}

Abdulah, S. and Mirajuddin, 2005. Pengaruh berbagai tingkat isi rumen sapi potong dalam konsentrat terhadap efisiensi penggunaan ransum kambing PE. J. Agroland. 12:181-186.

Aragona, M. and E.Z. Setz. 2001. Diet of the maned wolf, Chrysocyon brachyurus (Mammalia: Canidae), during wet and dry seasons at Ibitipoca State Park, Brazil. J. Zool. 254:131-136

Asih, A.R.S., K.G. Wiryawan and B.A.Young. 2011. Nitrogen utilization by dairy Goats offered different nitrogen sources as supllements in high isocaloric energy concentrates. J. Indonesian Trop. Anim. Agric. 36(1):36-42

Bonanno, A., V. Fedele and A. Di Grigoli. 2008. 
Grazing Management of Dairy Goats on Mediterranean Herbaceous Pastures. In : Dairy Goats Feeding and Nutrition. Editor : A. Cannas and G. Pulina. CAB International, Wallingford.

Camardella, A.R., M.F. Abreu and E. Wang. 2000. Marsupials found in felids scats is southern Brazil, and a range extension of Monodelphis theresa. Mammalia 64:379382.

Chanjula, P. and W. Ngapongsai. 2008. Effect of supplemental nitrogen from urea on digestibility, rumen fermentation pattern, microbial populations and nitrogen balance in growing goats Songklanakarin. J. Sci. Technol. 30(5):571.

Cunningham, J. M. and B. G. Klein. 2007. Veterinary Physiology. Fourth edition. Saunders, Elsevier, Missouri.

Decandia, M., M.D. Yiakoulaki, G. Pinna, A. Cabiddu and G. Molle. 2008. Foraging Behaviour and Intake of Goats Browsing on Mediterranean Shrublands. In : Dairy Goats Feeding and Nutrition. Editor : A. Cannas and G. Pulina. CAB International, Wallingford.

Devendra, C. and M. Burns. 1994. Produksi Kambing di Daerah Tropis. ITB Bandung (Translated by I.D.K. Harya Putra).

Drennan, M.J., J.H.G. Holmes and W. N. Garrett. 1970. A comparison of markers for estimating magnitude of rumen digestion. Br. J. Nutr. 24:961.

Fredin, S.M., L.F. Ferraretto, M.S. Akins, P.C. Hoffman, and R.D. Shaver. 2014. Fecal starch as an indicator of total-tract starch digestibility by lactating dairy cows. J. Dairy Sci. 97:1862-1871.

Hafez, E. S. E. and I. A. Dyer. 1969. Animal Growth and Nutrition. Lea and Febiger, Philadelphia.

Johnson, R. and W. Taylor. 2001. Skills for Midwifery Practice. Elsevier Science.

Kauhala, K. and M. Auniola. 2001. Diet of raccoon dogs in summer in the Finnish archipelago. Ecography 24:151-156.

Lukas, M., K. H. Sudekum, G. Rave, K. Friedel and A. Susenbeth. 2005. Relationship between fecal crude protein concentration and diet organic matter digestibility in cattle. J. Anim. Sci. 83:1332-1344.

Lykos, T. and G.A. Varga. 1995. Effects of processing method on degradation characteristics of protein and carbohydrate sources in situ. J. Dairy Sci. 78:1789-1801.

National Research Council (NRC). 1981. Nutrient Requirements of Goats: Angora, Dairy and Meat Goats in Temperate and Tropical Countries. National Academy Press, Washington, D.C.

Page, L.K., R.K. Swihart and K.R. Kazacos. 2001. Seed preferences and foranging by granivores at raccoon latrines in the transmission dynamics of raccoon roundworm (Baylisascaris procyonis). Can. J. Zool. 79:616-622

Patton, S., A. Rabinowitz, S. Randolph and S.S. Johnson 1986. A coprological survey of parasites of Neotropical Felidae. J. Parasitol. 72:517-520

Poppi, D. P., B. W. Norton, D. J. Minson and R. E. Hendricksen. 1980. The validity of the critical size theory for particles leaving the rumen. J. Agric. Sci. 94:275-280.

Preston, T. R. and R. A. Leng. 1987. Matching Ruminant Production Sistems with Available Resources in the Tropic and SubTropic. International Colour Production. Stanthorpe, Queensland, Australia.

Remond, D., J.I. Cabrera-Estrada, M. Champion, B. Chauveau, R. Coudure and C. Poncet. 2004. Effect of corn particle size on site and extent of starch digestion in lactating dairy cows. J. Dairy Sci. 87:1389-1399.

Santos, M.F.M. and S.M. Hartz. 1999. The food habits of Procyon cancrivorus (Carnivora, Procyonidae) in the Lami Biological Reserve, Porto Alegre, Southern Brazil. Mammalia 63:525-530.

Seton, E.T. 1925. On the study of scatology. J Mamm. 6: 47-49.

Steven, C.E., R.A. Argenzio and E.T. Clemens. 1979. Microbial digestion: Rumen versus Large Intestine. In: Digestive Physiology and Metabolism in Ruminant. Y. Ruckebusch and P. Thivend (Editors). Proceedings of the 5th International Symposium on Ruminant Physiology. MTP Press Limited. Lancaster.

Sudjana. 2005. Metode Statistika. Tarsito. Bandung.

Tillman, A.D., H. Hartadi, S. Reksohadiprodjo, S. Prawirokusumo and S. Lebdosoekojo. 1998. Ilmu Makanan Ternak Dasar. Gadjah Mada University Press, Yogyakarta.

Trana, A.D. and L. Sepe. 2008. Goat Nutrition for Fibre Production. In : Dairy Goats Feeding and Nutrition. A. Cannas and G. Pulina 
(Editors). CAB International, Wallingford. Ulyatt, M. J., D. W. Dellow, A. John, C. S. W. Reid, and G. C. Waghorn. 1986. Contribution of chewing during eating and rumination to the clearance of digesta from the ruminoreticulum. In: Control of Digestion and Metabolism in Ruminants: Proc. 6th Int. Symp. Ruminant Physiology. L. P. Milligan, W. L. Grovum, and A. Dobson (Editors). Prentice-Hall, Englewood
Cliffs, NJ. p 498-515.

Weller, R. A., A. F. Pilgrim and F. V. Gray. 1971. Level of food intake and the passage of markers and nitrogen along the alimentary tract of sheep. Br. J. Nutr. 26:487.

Zinn, R. A., A. Barreras, L. Corona, F. N. Owens and R. A. Ware. 2007. Starch digestion by feedlot cattle: Predictions from analysis of feed and fecal starch and nitrogen. J. Anim. Sci. 85:1727-1730 